A DIPLOMATIC HISTORY OF THE AMERICAN REVOLUTION 
This page intentionally left blank 


\title{
A DIPLOMATIC HISTORY OF THE
}

\author{
AMERICAN \\ REVOLUTION
}

Jonathan R. Dull

Yale University Press $•$ New Haven and London 
Copyright $\mathcal{O} 1985$ by Yale University. All rights reserved. This book may not be reproduced, in whole or in part, in any form (beyond that copying permitted by Sections 107 and 108 of the U.S. Copyright Law and except by reviewers for the public press), without written permission from the publishers.

Library of Congress Cataloging in Publication Data

Dull, Jonathan R., 1942-

A diplomatic history of the American Revolution.

Bibliography: p.

Includes index.

1. United States-Foreign relations-Revolution, 1775-1783.

I. Title

E249.D859 $1985 \quad 973.3^{\prime 2} \quad 85-5306$

ISBN 978-0-300-03886-6

The paper in this book meets the guidelines for permanence and durability of the Committee on Production Guidelines for Book Longevity of the Council on Library Resources. 
For Susan 


\section{EUROPE in 1763}

Possessions of:

13 King Frederic
7 Mrchauchess
Maria Theresa
4.

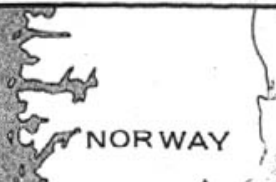

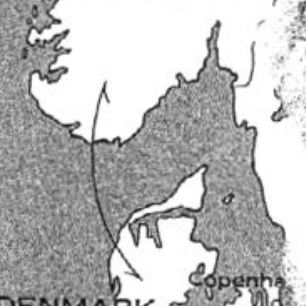

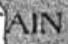

North Sea

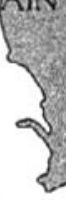

DENMARK
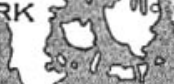

NETHERL YNDS

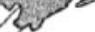

COear

NENGLAND

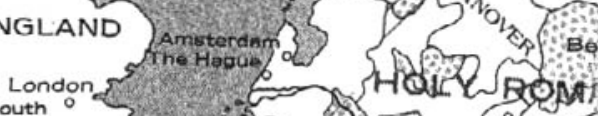

Plymgoth Portamouth

Scilly is:

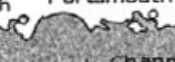

Dunkirk
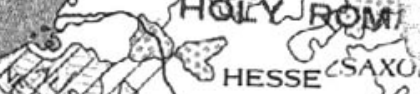

Axo.

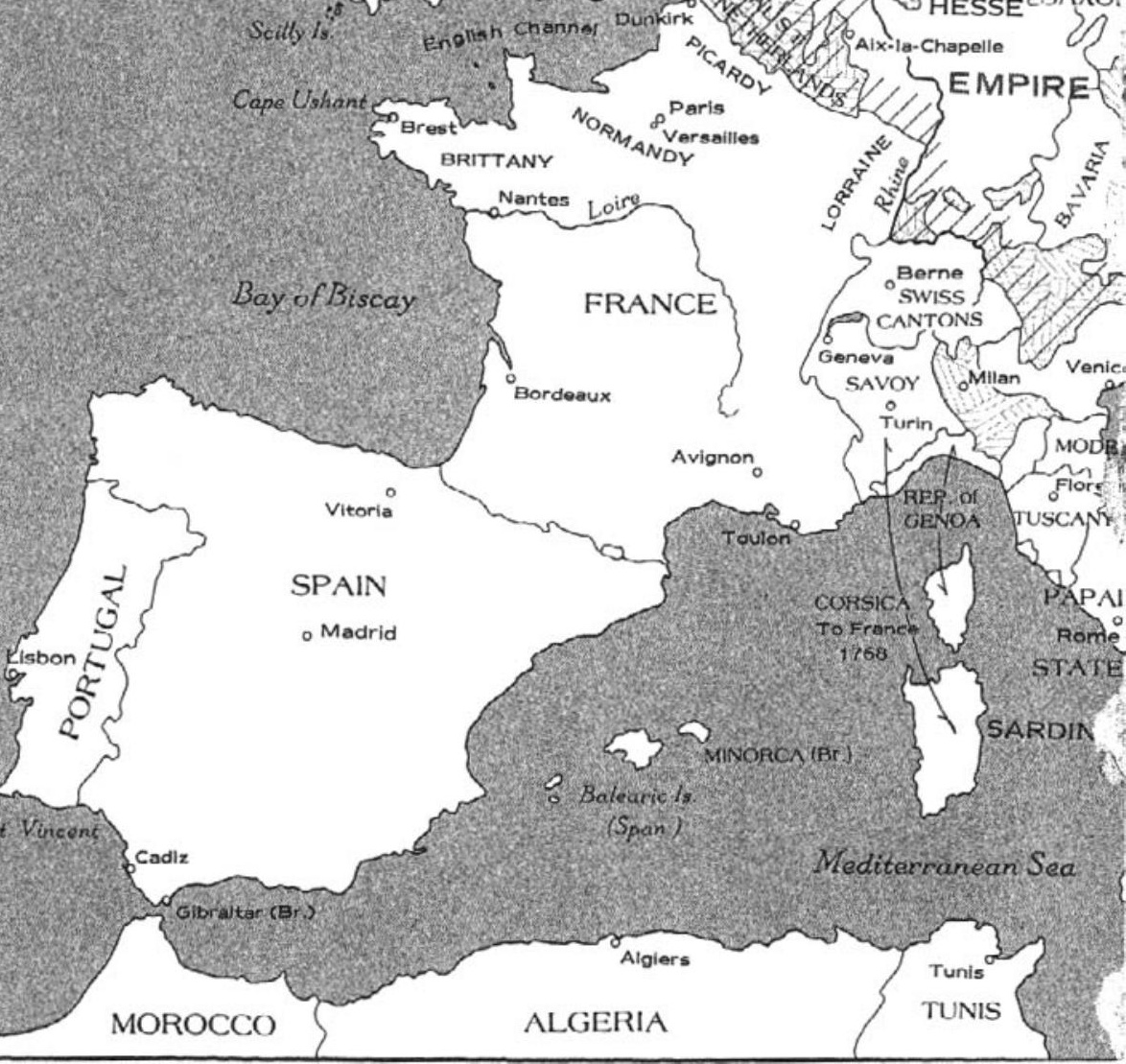




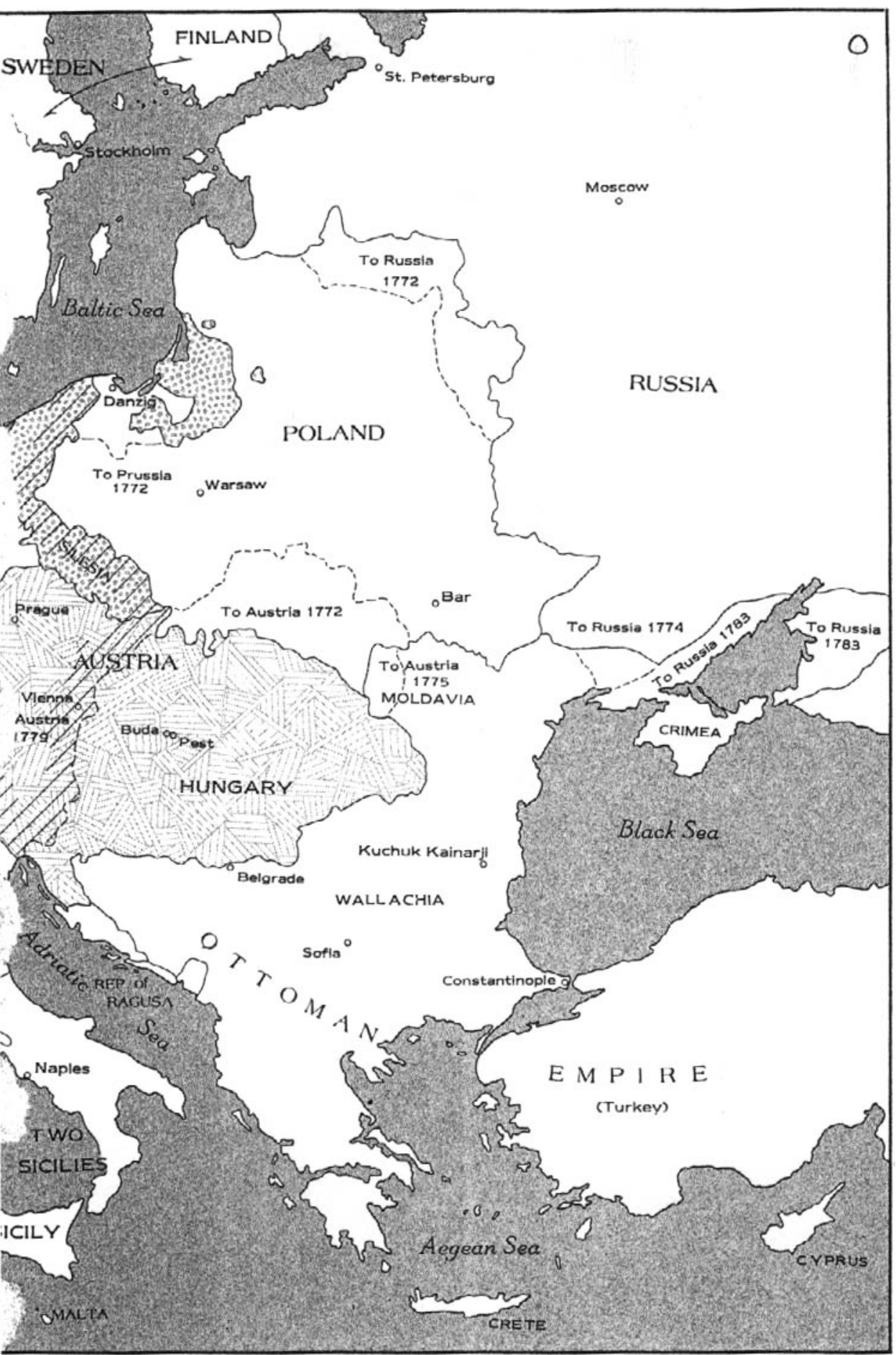


This page intentionally left blank 